\title{
Transfected human class I gene product adequately assembles minor histocompatibility antigens
}

\author{
Els Goulmy ${ }^{1}$, Jos Pool ${ }^{1}$, Els Blokland ${ }^{1}$, and Dan Geraghty ${ }^{2}$ \\ ${ }^{1}$ Department of Immunohaematology and Bloodbank, Univer sity Hospital, Leiden, The Netherlands \\ ${ }^{2}$ Fred Hutchinson Cancer Research Center, Seattle, USA
}

Received February 18, 1991, revised version recerved March 27, 1991

The success of HLA genotypically identical bone marrow grafting is still hampered by graft vs host disease and rejection of the graft. One of the causes of the latter complication could be attributed to minor histocompatibility (miH) antigen disparities between HLA genotypically identical siblings (Goulmy 1988). In previous in vitro studies, we demonstrated the presence of anti-host cytotoxic $\mathrm{T}$ cell $(\mathrm{CTL})$ as well as proliferative $(\mathrm{Th}) \mathrm{T}$ cell reactions in blood-samples taken after HLA identical bone marrow transplantation (van Els $1990 \mathrm{a}, \mathrm{b}$ ). The latter activities are directed against $\mathrm{miH}$ antigens which are recognized in association with MHC class I (CTL) and class II (Th) products (Goulmy 1988; van Els 1990c). We recently acquired CTL clones specific for five non-sexlinked $\mathrm{miH}$ antigens designated HA-1, $-2,-3,-4$, and -5 , whereby HA-1, $-2,-4$, and -5 use the HLA-A2 gene product as restriction molecule. Using the latter CTL clones, immunogenetic studies were carried out to determine the $\mathrm{miH}$ antigen gene frequencies and to study the $\mathrm{miH}$ antigen segregation patterns in families. One complication in these studies is that it is necessary for the HLA-A2 molecule to be present in order to detect the $\mathrm{miH}$ antigens. As illustrated in Figure 1a, the HLA-A2 positive identical siblings 02 and 03 carry miH antigens HA- 1 and -2 . Since the father (01) of family B orly posseses HA-2, the $\mathrm{miH}$ antigen HA-1 must have been inherited from the mother. Therefore, the absence of the required MHC class I HLAA2 restricting antigen hampers adequate genetic analysis in this and other families.

In order to solve this deficit, we used electroporation (Potter et al. 1984) to introduce cloned HLA genes into the Epstein-Barr transformed B cell lines of selected members of this family. We transfected the HLA-A2 gene cloned in the pHEBO vector (Sugden et al. 1985; Shimizu et al. 1986) into the HLA-A2 negative cells of the mother

Address correspondence and offprint requests to $\mathrm{E}$ Goulmy, Depart ment of Immunohaematology, Bldg I E3-Q, University Hospital, PO Box 9600,2300 RC Lexden, The Netherlands.
(00) and into three HLA identical, HLA-A2 negative family members 04, 05, and 06 (Fig. 1a). Fluorescence activated cell sorter (FACS) analyses using the class I and HLA-A2 specific monoclonal antibodies were carried out and demonstrated the surface expression of the HLA-A2 gene product on all transfected cells (Fig. 2). Subsequently, the transfected cell lines were subjected to $\mathrm{miH}$ typing. Figure $1 \mathrm{~b}$ shows that we were indeed able to trace the $\mathrm{miH}$ antigen HA-1, which after $H L A-A 2$ gene transfection appeared to be inherited from the mother $(00)$. Furthermore, the cells from three children $(04,05,06)$ who did not carry the $\mathrm{A} 2$ allele and thus could not be tested for the presence of $\mathrm{miH}$ antigen HA-1 and -2 , were now amenable to the CTL analysis. In addition to using the $\mathrm{miH}$ HA-1 and HA-2 specific CTL clones, we also tested HLA-A2 allospecific and HLA-A2 restricted H-Y specific CTL clones on the cells of all family members. As shown in Figure 1b, A2 allo-specific, A2 restricted $\mathrm{miH}$ antigen $\mathrm{H}-\mathrm{Y}$, HA-1, and HA-2-specific CTLs lysed the transfected cells to the same extent as the naturally expressing HLA-A2 cells. To confirm that we were actually dealing with identical $\mathrm{MHC} / \mathrm{miH}$ antigen peptide complexes, cold target inhibition studies were carried out. Table 1 shows that HLA-A2 transfectants were equally potent as cold target inhibitors of HLA-A2 directed lysis as their naturally expressing HLA-A2 counterparts. Non-transfected target cells failed to show any inhibition.

In conclusion, we have used gene transfection to circumvent the lack of the required MHC restriction molecule for $\mathrm{miH}$ antigens $\mathrm{HA}-1,-2$, and $\mathrm{H}-\mathrm{Y}$ recognition. Similar to the naturally expressed A2 gene products, the transfected gene products associate with the $\mathrm{miH}$ peptide(s) creating an assemblage suitable for $\mathrm{A} 2 / \mathrm{miH}$ antigen specific T-cell receptor recognition. Recognition of human miH antigens upon implantation or by gene transfection of the required HLA antigens has been reported previously (Zier et al. 1987, Yamamoto et al. 1990). Our results are in line with both latter reports. The data shown here clearly demonstrate that gene transfection yields cell 
- HA 1

- HA 2

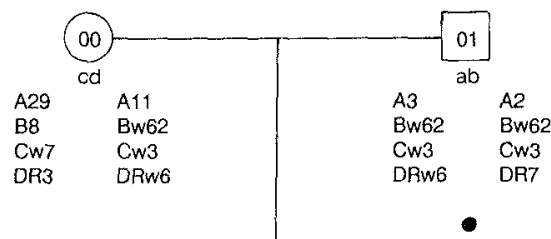

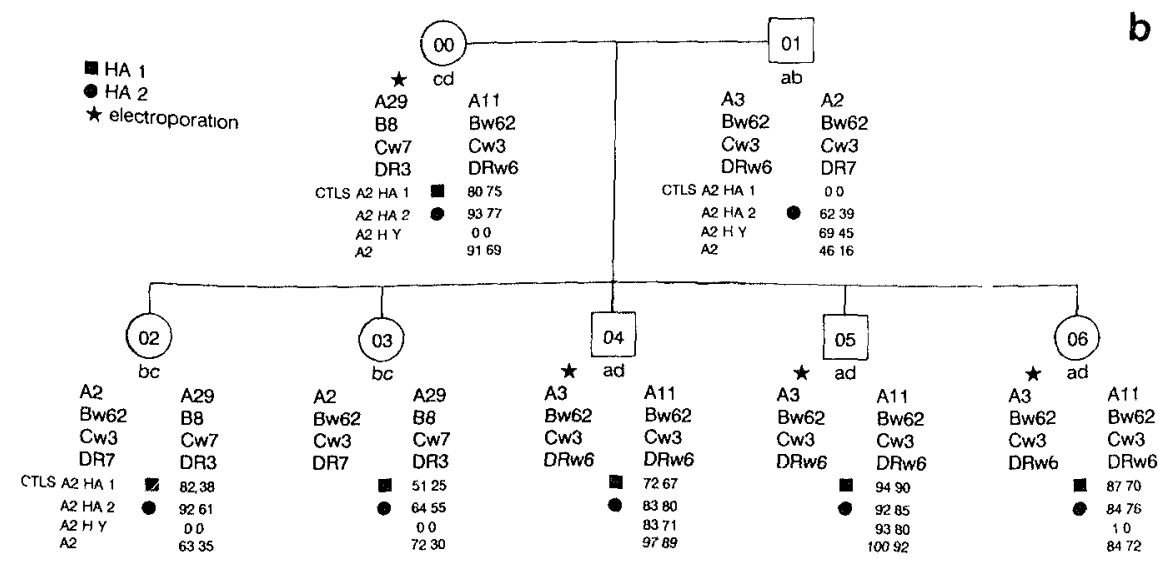

b

Fig. 1. a, b. The presence of the $\mathrm{miH}$ antigens HA-1 and HA-2 is indicated by their specific symbols The \% specific lysis obtained from the different CTL clones at two effector to target ratios ( $1 \mathrm{e}, 201$ and 2 1) is shown * indicates that cells underwent HLA-A2 gene transfection, $\square$ males, $O$ females
04

Antibody $9 E 8$

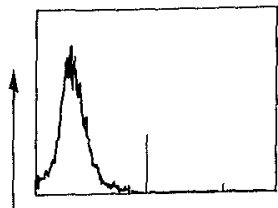

Antibody P2O 1

$04+A 2$

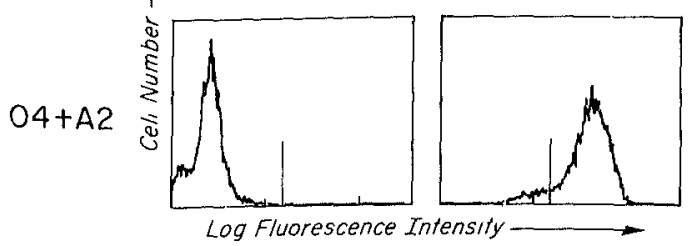

Log Fluorescence Intensity

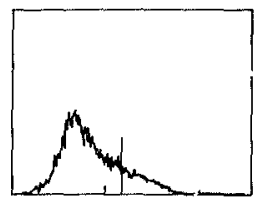

Fig. 2. The EBV LCLs of family members 00, 04, 05, and 06 were transfected by electroporation (Potter et al 1984) using the HLA-A2 gene cloned in the pHEBO vector (Shimizu et al 1986) Selected cell growth was made possible by the presence of hygromycine $\mathbf{B}$ The cells were staned by a standard indrect fluorescence technique using the indicated monoclonal antibodies and FITC labeled goat ant1-mouse and analyzed on a FACS analyzer 
Table 1. Comparison of HLA-A2 transfectants and naturally HLA-A2 expressing cells as cold target inhibitors of HLA-A2 directed lysis

\begin{tabular}{|c|c|c|c|c|c|}
\hline \multicolumn{2}{|c|}{ Target cells } & \multicolumn{4}{|c|}{ Cytotoxic $\mathrm{T}$ cell clones } \\
\hline hot & cold & allo $\mathrm{A} 2$ & $\mathrm{~A} 2 \mathrm{HY}$ & A2HA 1 & A2HA-2 \\
\hline $00^{*}$ & none & $97 / 54^{\dagger}$ & $1 / 4$ & $90 / 81$ & $70 / 25$ \\
\hline $00^{*}$ & 00 & $87 / 47$ & & $84 / 69$ & $78 / 28$ \\
\hline $00^{*}$ & $00^{*}$ & $60 / 9$ & & $70 / 20$ & $35 / 3$ \\
\hline $00^{*}$ & $04^{*}$ & $67 / 14$ & & $67 / 21$ & $33 / 3$ \\
\hline $00^{+}$ & 03 & $74 / 28$ & & $87 / 56$ & $44 / 6$ \\
\hline $04 *$ & none & $85 / 54$ & $82 / 70$ & $82 / 70$ & $70 / 25$ \\
\hline $04+$ & 04 & $87 / 65$ & $82 / 64$ & $89 / 64$ & $66 / 25$ \\
\hline $04 *$ & $04 *$ & $49 / 12$ & $65 / 17$ & $55 / 22$ & $26 / 3$ \\
\hline $04^{*}$ & $00^{+}$ & $52 / 18$ & $84 / 74$ & $57 / 16$ & $36 / 7$ \\
\hline $04+$ & $01^{*}$ & $65 / 41$ & $64 / 53$ & $79 / 69$ & $33 / 10$ \\
\hline 01 & none & $60 / 27$ & $62 / 54$ & $2 / 2$ & $49 / 15$ \\
\hline 01 & 01 & $40 / 9$ & $41 / 19$ & & $31 / 1$ \\
\hline 01 & $00^{*}$ & $16 / 0$ & $67 / 50$ & & $21 / 3$ \\
\hline 01 & 04 & $57 / 33$ & $71 / 47$ & & $56 / 15$ \\
\hline 01 & $04^{*}$ & $17 / 2$ & $34 / 2$ & & $18 / 0$ \\
\hline 01 & 03 & $32 / 3$ & $72 / 57$ & & $23 / 4$ \\
\hline 03 & none & $73 / 40$ & $0 / 0$ & $47 / 32$ & $53 / 19$ \\
\hline 03 & 03 & $44 / 8$ & & $25 / 7$ & $31 / 4$ \\
\hline 03 & 00 & $67 / 32$ & & $40 / 23$ & $61 / 24$ \\
\hline 03 & $00^{+}$ & $30 / 3$ & & $7 / 0$ & $30 / 7$ \\
\hline 03 & $04 *$ & $27 / 1$ & & $13 / 0$ & $27 / 3$ \\
\hline
\end{tabular}

* Indicates the cells underwent tiansfection

$\%$ Specific lysis at two effector/target ratio, 1 e, 201 and 21

* Note that 01 is HA-1 negative but HA-2 positive

The generation of $\mathrm{miH}$ antigen specific CTLs has been described in detall (Goulmy 1988) Specific cytotoxic T cell activity was medsured by the cell-mediated lympholysis assay previously described (Goulmy 1982) The hot cold target cell ratio used is 110

surface expressed MHC products resulting not only in high levels of specific lysis by both allo- and MHC restricted $\mathrm{mIH}$ antigen specific CTLs, but also in comparable inhibiting capacities. Consequently, gene transfection has proved to be a reliable technique for adequate $\mathrm{miH}$ antigen recognition and thus broadens its immunogenetic analyses

Acknowledgments This work was supported by the J A Cohen Inst1 tution for Radiopathology and Radiation Protection (IRS)

\section{References}

Els, C A C M van, Bakker, A, Zwinderman, A H, Zwdan, F E, Rood, $\mathrm{J} J$ van, and Goulmy, E Effector mechanisms in graftversus-host disease in response to minor histocompatibility anti gens I Absence of correlation with cytotoxic effector cells Transplantation $506266,1990 \mathrm{~d}$

Els, C A C M van, Bakker, A, Zwinderman, A H, Zwadn, F E, Rood, J J van, and Goulmy, E Effector mechanısms in graft versus-host disedse in response to minor histocompatibility an trgens II Evidence of a possible involvement of prohferative $\mathrm{T}$ cells Transplantation $50 \quad 67-71,1990 \mathrm{~b}$

Els, C A C M van, Zantvoort, E, Jacobs, N, Bakker, A, Rood, J J van, and Goulmy, E Graft-versus host disease dssoctated Thelper cell responses specific for minor histocompatibility antigens are manly restricted by HLA-DR molecules Bone Marrow Transplant 5 365-372, 1990c

Goulmy, E HLA A, B restriction of cytotoxic $\mathrm{T}$ cells In $S$ Ferrone and $B G$ Solheim (eds) HLA Typing Methodology and Clinical Aspects, Vol 2, pp 105-122, CRC Press, New York, 1982

Goulmy, E Minor histocompatibility antigens in man and their role in transplantation In P J Morrs and $\mathrm{N} \mathrm{L}$ Tilney (eds) Fransplantation Revtews, Vol 2, pp 29-53, W B Saunders, 1988

Potter, H, Weir, L, and Leder, P Enhancer-dependent expression of human $\mathrm{k}$ immunoglobulin genes introduced into mouse pre-B lymphocytes by electroporation Proc Natl Acad SCI USA 81 $7161-7165,1984$

Shımıı Y , Koller, B , Geraghty, D , Orr, H , Shaw, S , Kavathas, $P$, and De Mars, $R$ Transter of cloned human class I major histocompatibulity complex genes into HLA mutant human lym phoblastord cells Mol Cell Biol 6 1074-1087, 1986

Sugden, B , Marsh, K, and Yates, J A vector that replicates as a plasmid and can be efficiently selected in B lymphoblasts transformed by Epstein Barr vilus Mol Cell Biol 5 410-413, 1985

Yamamoto, J , Karıone, A , Akıyama, N, Kano, K , and Takıguchı, $M$ Presentation of human minor histocompatıbility antigens by HLA B35 and HLA-B38 molecules Proc Natl Acad SA USA 87 2583-2587, 1990

Zier, K S, Volsky, D J, and Sinangl, F The detection of human minor alloantigens following restriction determinant implantation Hum Immunol 19 17-27, 1987 